\title{
Development of New Polymorphic Microsatellite Markers for Three Closely Related Plant-Pathogenic Phytophthora Species Using 454-Pyrosequencing and Their Potential Applications
}

\author{
Corine N. Schoebel, Esther Jung, and Simone Prospero
}

Swiss Federal Institute for Forest, Snow and Landscape Research WSL, CH-8903 Birmensdorf, Switzerland. Accepted for publication 12 April 2013.

\begin{abstract}
Schoebel, C. N., Jung, E., and Prospero, S. 2013. Development of new polymorphic microsatellite markers for three closely related plant-pathogenic Phytophthora species using 454-pyrosequencing and their potential applications. Phytopathology 103:1020-1027.

Phytophthora spp. (oomycetes) are causal agents of devastating diseases on a high number of crops, ornamentals, and native plants worldwide. Neutral molecular markers are increasingly being used to investigate the genetic population structure and possible pathways of spread of different plant pathogens, including Phytophthora spp. In this study, polymorphic microsatellite markers were developed for three species of the former Phytophthora citricola species complex-namely,

vora, and 8 for $P$. pini. Microsatellites with dinucleotide motifs repeated 6 to 10 times were the most common for all three species. On average, 65 alleles per species and 5.3 alleles per locus were detected. Most loci were characterized by a low observed heterozygosity, which might be due to the homothallic mating system of the three Phytophthora spp. targeted. Cross amplification of the newly developed markers was tested on 17 Phytophthora spp. belonging to five different internal transcribed spacer clades. Transferability success was generally low and decreased with increasing genetic distance from the species to the three target species. A set of four loci was selected to easily discriminate $P$. plurivora, $P$. multivora, and $P$. pini on the basis of presence or absence of a polymerase chain reaction amplicon on an agarose gel.
\end{abstract} $P$. multivora, $P$. plurivora, and $P$. pini $(P$. citricola $\mathrm{I})$ - using the 454pyrosequencing technique. In total, 35 polymorphic microsatellite loci were found and further characterized: 11 for P. plurivora, 16 for P. multi-
Additional keywords: species identification.
Plant pathogens and pests are increasingly being spread around the globe through human-mediated commercial trading in live plants (e.g., nursery stock) and plant material. The introduction of a pathogenic organism may result in a biological invasion with catastrophic ecological and economic consequences (9,30). After viruses, fungi in a broad sense (including fungal-like organisms, such as oomycetes) are the second most important taxonomic group responsible for biological invasions (3). Well-known invasive fungal pathogens in forest ecosystems are, for example, the white pine blister rust fungus Cronartium ribicola in North America (31) and, more recently, the ascomycete Hymenoscyphus pseudoalbidus, which has been responsible for the severe dieback affecting common ash (Fraxinus excelsior) in Europe (34).

Species of the genus Phytophthora (Stramenopila, Oomycetes) are known to cause devastating diseases on a great number of crops, ornamentals, and native plants worldwide (14). The most famous example is presumably Phytophthora infestans, the causal agent of the so-called "Irish potato famine" in the 19th century $(7,38)$. Many other significant recent declines and dieback phenomena in forest ecosystems worldwide have also been associated with Phytophthora spp. (e.g., sudden oak death in North America [20] and Daño Foliar del Pino in Chile [11]). Most of these species are considered to be exotic in the ecosystems they have invaded and damaged. Specific studies conducted in Europe and North America $(18,37)$ have clearly shown that nursery trading is

Corresponding author: C. N. Schoebel; E-mail address corine.schoebel@wsl.ch

* The $e$-Xtra logo stands for "electronic extra" and indicates that the online version contains two supplemental tables.

http://dx.doi.org/10.1094/PHYTO-01-13-0026-R

(c) 2013 The American Phytopathological Society a main pathway for the dispersal of Phytophthora spp. Given the increase in international trade, a growing number of Phytophthora spp. can be expected to be spread around the world artificially within a short time.

Population genetic approaches have proven to be particularly appropriate for investigating the evolutionary history, epidemiology, and dispersal of pathogenic organisms. For example, using neutral molecular markers, it is possible to reconstruct the main pathways of spread of cosmopolitan or invasive plant pathogens, including those of several Phytophthora spp. $(12,18)$. At the same time, the analysis of the genetic diversity of different populations of a specific pathogen may help to identify the possible center of origin and reproductive mode of a particular organism.

Microsatellites, which are also known as simple-sequence repeats, are short, tandem-repeated motifs of 1 to 6 bases and are currently one of the most popular molecular markers. Key benefits of microsatellites are that they are very abundant in the genome of most organisms and assumed to be neutral, co-dominant (i.e., at a heterozygous locus both alleles are visible), and highly variable $\left(10^{-6}\right.$ to $10^{-2}$ mutation rates per generation) $(16,23)$. Moreover, they are easy to score, and results obtained with microsatellites are highly reproducible. The major drawback of microsatellites is that they need to be developed de novo for each target organism when it is investigated for the first time because cross-amplification from other species is rarely effective and may produce unreliable results $(4,45)$. However, the advent of new molecular techniques in recent years (e.g., 454-pyrosequencing) has considerably facilitated the identification and characterization of quality microsatellite markers in non-model species (42).

Thus far, polymorphic, species-specific microsatellite markers have been developed and applied for population genetic studies in only few Phytophthora spp. occurring in forest ecosystems-for 
example, $P$. alni subsp. uniformis (2), $P$. ramorum $(22,38)$, and $P$. cinnamomi (10). This is particularly unsatisfying considering that Phytophthora spp. are increasingly thought to play a considerable role in forest decline worldwide. Without appropriate molecular markers, it is difficult to study the population biology of emerging pathogens (e.g., their genetic diversity, population dynamics, and evolutionary potential).

The homothallic P. citricola was first identified in 1927 on citrus in Taiwan (41). It has since been found worldwide on a wide variety of plants and, therefore, was first considered to be cosmopolitan. Because of the high morphological and molecular variation observed within isolates, however, it was later thought to be a species complex. Recently, based on DNA sequences, Jung and Burgess (26) showed that the P. citricola complex actually comprises four species: namely, $P$. multivora, $P$. plurivora, $P$. pini ( $P$. citricola $\mathrm{I}$ ), and $P$. citricola sensu stricto. These species have different geographic distributions and host ranges. $P$. plurivora is frequent in forests, semi-natural ecosystems, and nurseries in Europe, where it has been involved in widespread European beech (Fagus sylvatica) and oak (Quercus sp.) declines $(24,25)$. It has also been found in plantations and nurseries in North America. P. multivora has a wide host range (e.g., Eucalyptus marginata and E. gomphocephala) in native forests of Western Australia (44). In Europe, this species is mostly restricted to nurseries. Finally, $P$. pini mainly infects $F$. sylvatica in the Eastern United States (21). All three Phytophthora spp. cause the same symptoms on their hosts: namely, fine root destruction, collar rot, and aerial bark cankers. P. citricola sensu stricto, the fourth species of the former $P$. citricola complex, causes brown rot on Citrus spp. and has been found in Taiwan, Japan, and Argentina and in European nurseries and plantations.

This study is intended as a contribution to increasing our knowledge about emerging pathogens. Therefore, we first isolated and characterized species-specific polymorphic microsatellite loci for three of the four Phytophthora spp. within the former $P$. citricola species complex (i.e., P. plurivora, $P$. multivora, and $P$. pini). Instead of using the traditional method for microsatellite development (i.e., construction of a genomic library highly enriched for specific microsatellite motifs) (52), we adopted a state-of-the-art 454-pyrosequencing-based method (1). A similar approach was already chosen by Aguayo et al. (2) for P. alni subsp. uniformis. This method will most likely be used more in future because sequencing costs have been decreasing and more sequences are being made available in public databases. We also tested all newly developed polymorphic microsatellite loci for transferability to a wide range of Phytophthora spp. from multiple internal transcribed spacer (ITS) clades (6). Finally, we developed a new, cost-efficient, and technically straightforward method for discriminating the four species of the $P$. citricola species complex using a combination of four microsatellite loci.

\section{MATERIALS AND METHODS}

Isolates. We considered 221 Phytophthora isolates belonging to three of the four species of the former $P$. citricola species complex. Due to the limited number of specimens available, $P$. citricola sensu stricto could not be included in the complete microsatellite marker development process. Nonetheless, six $P$. citricola sensu stricto isolates from France, Italy, and Japan were considered in the cross-species amplification tests (see below). For P. plurivora, 77 isolates obtained from four populations (France, 22 isolates; Oregon, U.S., 18 isolates; Slovenia, 15 isolates; and Southern Germany, 22 isolates) were used. For $P$. multivora, 57 isolates belonging to two populations (12 from New Zealand and 45 from Australia) were included for microsatellite marker development. Finally, 77 P. pini isolates from three populations were included (18 from Europe, 22 from the United States east coast, and 37 from Oregon, U.S.).
Sample preparation. All isolates were grown on potato dextrose agar at $39 \mathrm{~g} /$ liter (Difco, Voight Global Distribution, Lawrence, MD). After 5 days of incubation at room temperature, one agar plug was transferred to a liquid-clarified V8 medium (modified after Miller [36]). Three to four days later, mycelia were harvested through filtration and immediately frozen at $-20^{\circ} \mathrm{C}$. For DNA isolation, the frozen mycelia were carefully transferred into a 96-well collection plate of the DNeasy Plant Kit (Qiagen, Valencia, CA) and lyophilized. Subsequently, 5-mm steel beads were added to each well, and the samples were shredded on a mill (Retsch, MM330) for $3 \mathrm{~min}$ at 14,000 rpm before DNA isolation using the Qiagen Kit according to the manufacturer's protocol.

Phytophthora spp. identification. Prior to the microsatellite analyses, the species identity of all isolates was determined by sequencing the ribosomal ITS region and the nuclear $\beta$-tubulin $(\beta$-tub) gene. The polymerase chain reaction (PCR) reaction mixture, PCR conditions, clean up of the PCR products, and sequencing reactions are described in detail by Blair et al. (6). For PCR amplification, the following primer sets were used: ITS-6 $\left(5^{\prime}\right.$ GAA GGT GAA GTC GTA ACA AGG $3^{\prime}$; [8]) and ITS-4 (5' TCC TCC GCT TAT TGA TAT GC $3^{\prime}$; [51]), $\beta$-tub F1 (5' GCC AAG TTC TGG GAG GTC ATC $3^{\prime}$ ) and $\beta$-tub R1 (5' CCT GGT ACT GCT GGT ACT CAG 3'), both (6). PCR clean up was performed using the Illustra Exo Star 1-Step PCR Clean up Kit (Thermo Fisher Scientific, Waltham, MA), while the BigDye Terminator v. 3.1. Cycle Sequencing Kit and the Big Dye XTerminator Purification Kit (Applied Biosystems, Carlsbad, CA) were used for sequencing, all according to the manufacturers' protocol. All sequences were run on a 3730xl DNA Analyzer (Applied Biosystems) and were manually checked and edited to obtain a consensus sequence using the software DNA Dynamo (http://www.bluetractorsoftware.co.uk/) and CLC Main Workbench v. 6.6.2 (http://www.clcbio.com). Sequences of all samples were then aligned with the sequences of the four reference samples CBS 29529, P. citricola sensu stricto; CBS 18125, P. pini; CBS 124087, P. plurivora; and CBS 124094, P. multivora), obtained from the CBS-KNAW Fungal Biodiversity Centre's culture collection (http://www.cbs.knaw.nl/index.php/collection).

454-Pyrosequencing. For each of the four Phytophthora spp. of the former $P$. citricola complex, one type isolate was selected from the CBS culture collection (CBS 29529, P. citricola sensu stricto; CBS 18125, P. pini; CBS 124087, P. plurivora; and CBS 124094, $P$. multivora). Subsequently, whole genome 454-pyrosequencing using a Roche GS FLX sequencer was used to generate enough random sequences to isolate a satisfying number of microsatellite loci by chance (1). Library preparation and sequencing were performed by Microsynth AG (Balgach, Switzerland; http://www.microsynth.ch/), according to the technique described by Margulies et al. (32). Shotgun libraries were prepared using the GS FLX Titanium Rapid Library Preparation Kit (Roche Diagnostics, Basel, Switzerland), while Microsynth provided the barcode adaptors. A GS FLX Titanium SV emPCR Kit (Lib-L), a GS FLX Titanium Sequencing Kit XLR70, and a GS FLX Titanium PicoTiterPlate Kit 70x75 (all by Roche) were also used. A run 2/16 of a full run was performed on a pooled sample of the four species.

Microsatellite and primer selection. Given that all the sequences obtained should be randomly distributed over the whole genome, the unassembled sequences were directly screened for perfect di-, tri-, and tetranucleotide microsatellites using MSATCOMMANDER, version 0.8.2 (15). Microsatellites with motifs repeated at least six times were chosen, because longer and perfect microsatellites are usually more variable (48). For $P$. plurivora, a rather low number of microsatellites with optimal primer positioning was found using the strict criteria of MSATCOMMANDER. A search for additional microsatellite loci consisting of five repeat units was thereafter performed. All reads 
containing microsatellites were aligned to detect any duplication of sequences between reads.

For each microsatellite locus, primer pairs were developed with PRIMER3 (40) implemented in MSATCOMMANDER using the default parameters. The primers were designed to meet the following criteria: amplification of products within a size range of 100 to $500 \mathrm{bp}$, optimal melting temperature of $60^{\circ} \mathrm{C}$ (range 57 to $62^{\circ} \mathrm{C}$ ), optimal GC content of $50 \%$, possession of at least one 1-bp GC clamp at the $3^{\prime}$ end, low levels of self- or pair-complementarity, and maximum end-stability $(\Delta \mathrm{G})$ of 8.0 (15) (http://biotools. umassmed.edu/bioapps/primer3_www.cgi). The option "Design Primers", in which the software searches for microsatellite repeats and identifies possible primer annealing sites in one single step, was included but no primer tagging option was chosen.

PCR amplification and fragment analysis. Positive PCR amplification and polymorphism of the microsatellite loci selected were initially tested on a subset of 16 isolates per species. For PCR amplification, forward primers labeled with an M13 tag (5' TGT AAA ACG ACG GCC AGT 3') were used (43). PCR reactions were performed with the Type-it Microsatellite PCR Kit (Qiagen) according to the manufacturer's protocol, except for the Type-it PCR MasterMix, of which only $3 \mu \mathrm{l}$ per reaction were used. PCR conditions were set as follows: initial denaturation for $5 \mathrm{~min}$ at $95^{\circ} \mathrm{C}$; followed by 28 cycles consisting of $30 \mathrm{~s}$ at $95^{\circ} \mathrm{C}, 90 \mathrm{~s}$ at $58^{\circ} \mathrm{C}$, and $30 \mathrm{~s}$ at $72^{\circ} \mathrm{C}$; then, for M13-tag binding, 8 cycles consisting of $30 \mathrm{~s}$ at $95^{\circ} \mathrm{C}, 90 \mathrm{~s}$ at $53^{\circ} \mathrm{C}$, and $30 \mathrm{~s}$ at $72^{\circ} \mathrm{C}$; with a final extension of $20 \mathrm{~min}$ at $60^{\circ} \mathrm{C}$.

To characterize the polymorphic $P$. plurivora and $P$. multivora microsatellite loci on a larger number of isolates, fluorescent forward primers were used and the PCR protocol was adjusted to $5 \mathrm{~min}$ at $95^{\circ} \mathrm{C}$; followed by 27 cycles consisting of $30 \mathrm{~s}$ at $95^{\circ} \mathrm{C}$, $90 \mathrm{~s}$ at $59^{\circ} \mathrm{C}\left(58^{\circ} \mathrm{C}\right.$ for $P$. pini), and $30 \mathrm{~s}$ at $72^{\circ} \mathrm{C}$; with a final extension of $30 \mathrm{~min}$ at $60^{\circ} \mathrm{C}$. PCR amplifications were performed on Veriti thermocyclers (Applied Biosystems). Subsequently, the PCR products obtained were run on a 3730xl DNA Analyzer (Applied Biosystems) with LIZ 500 as the size standard (G5) for fragment analysis. All fragments were scored using GeneMapper (version 3.7; Applied Biosystems). Microsatellites for P. citricola sensu stricto could not be tested for polymorphism due to the lack of a sufficient number of isolates.

Population genetic analyses. All microsatellite loci that showed polymorphism on the subset of isolates for each Phytophthora sp. were further characterized on three (P. multivora and $P$. pini) or four (P. plurivora) populations. For each locus, the number of alleles was calculated, as were the observed and expected heterozygosities and inbreeding coefficient $\left(\mathrm{F}_{\mathrm{IS}}\right)$ using the software Genetix (5). For each Phytophthora sp., any possible gametic linkage disequilibrium (50) between all pairs of loci was tested using the software FSTAT 2.9.3.2 (19). Subsequently, Bonferroni correction was applied.
Cross-species transferability of microsatellite loci. Crossspecies amplification of all 35 newly developed microsatellite markers was tested on a range of 17 Phytophthora spp. belonging to five different ITS clades (6). Each microsatellite locus was tested for positive PCR amplification with all four species of the former $P$. citricola species complex, as well as with two isolates of each of the following species: $P$. cactorum (clade 1); P. citrophthora, $P$. inflata (one isolate only), and $P$. mengei (clade 2); $P$. quercina (one isolate only, clade 4); $P$. gonapodyides, P. taxon pg chlamydo (one isolate only), and $P$. megasperma (clade 6); $P$. cambivora and $P$. cinnamomi (clade 7); and $P$. cryptogea, $P$. syringae (one isolate only), and P. ramorum (clade 8 ). PCR conditions were set as described above (PCR amplification and fragment analysis), and PCR products were run on a 3730xl DNA Analyzer (Applied Biosystems) with LIZ 500 as the size standard. All fragments were scored using GeneMapper (version 3.7; Applied Biosystems).

Species identification using four newly developed microsatellite markers. In order to easily identify $P$. plurivora, $P$. multivora, $P$. pini, and $P$. citricola sensu stricto, a set of four microsatellite loci was selected (PpMs03, PpMs16, PmMs20, and PmMs04). All loci were amplified by PCR on Veriti thermocyclers (Applied Biosystems) with the Type-it Microsatellite PCR Kit from Qiagen, as described above. For all loci apart from PpMs16, $0.2 \mu \mathrm{l}$ of each primer was used in the PCR reaction $($ PpMs 16: $0.6 \mu \mathrm{l})$. Each locus was amplified separately using the following protocol: $5 \mathrm{~min}$ at $95^{\circ} \mathrm{C}$; followed by 27 cycles consisting of $30 \mathrm{~s}$ at $95^{\circ} \mathrm{C}, 90 \mathrm{~s}$ at $59^{\circ} \mathrm{C}\left(\mathrm{PpiMs} 03,58^{\circ} \mathrm{C}\right)$, and $30 \mathrm{~s}$ at $72^{\circ} \mathrm{C}$; and a final extension of $30 \mathrm{~min}$ at $60^{\circ} \mathrm{C}$. Subsequently, PCR amplicons of each locus were scored for successful amplification on $1.5 \%$ agarose gels. Species were identified according to the amplification or nonamplification patterns (i.e., to the presence or absence of PCR amplicon) at the different loci.

\section{RESULTS}

454-Pyrosequencing. From $2 / 16$ of a full 454-pyrosequencing run, 70,352 reads with an average length of 376.8 bp were obtained for the four species of the $P$. citricola complex. The total number of reads found for each species was between 15,009 (P. citricola sensu stricto) and 20,716 (P. multivora) (Table 1). Analyses conducted with the software MSATCOMMANDER detected a total of 341 reads that contained perfect di-, tri-, and tetranucleotide microsatellite loci, with motifs repeated at least six times. The number of microsatellite loci found in different species differed greatly, from 62 (P. plurivora) to 110 (P. multivora). After widening the search criteria by including microsatellites with motifs repeated only five times and manually optimizing the primer design, 19 additional microsatellite loci were found for P. plurivora (Table 1).

TABLE 1. Additional details on the microsatellite development sorted by the four species of the Phytophthora citricola species complex: P. plurivora, $P$. multivora, $P$. pini, and P. citricola sensu stricto

\begin{tabular}{|c|c|c|c|c|}
\hline Species specific marker detail & P. plurivora & P. multivora & P. pini & P. citricola sensu stricto \\
\hline Sample ID & CBS124087 & CBS124094 & CBS18125 & CBS29529 \\
\hline Country of origin, isolation year & Germany, 1994 & Australia, 2007 & United States, 1925 & Japan, 1929 \\
\hline DNA concentration $(\mathrm{ng} / \mu \mathrm{l})$ & 47 & 28 & 33 & 34 \\
\hline Number of sequences with SSRs $(>6 \text { repeats })^{a}$ & 62 & 110 & 71 & 98 \\
\hline Number of primer pairs found in silico & 17 & 38 & 14 & 26 \\
\hline Number of additional primer pairs designed/loci detected ${ }^{\mathrm{b}}$ & 19 & - & - & - \\
\hline Number of primer pairs tested ${ }^{c}$ & 36 & 24 & 13 & 0 \\
\hline No. of multiplex PCRs & 3 & 4 & - & - \\
\hline
\end{tabular}

${ }^{\text {a }}$ SSR $=$ simple-sequence repeat.

${ }^{\mathrm{b}}$ Additional primer pairs were searched only for P. plurivora (see Materials and Methods).

${ }^{\mathrm{c}}$ Microsatellite in $P$. citricola sensu stricto were not tested for polymorphism because of the lack of a sufficient number of samples. 
Dinucleotide microsatellites were the most common loci detected across all four Phytophthora spp. (76.9\% of the microsatellite loci) (Supplemental Table 1). In contrast, trinucleotide and, especially, tetranucleotide microsatellites were considerably less abundant in all species (20.2 and $2.9 \%$, respectively). Within all three categories of microsatellites, those with motifs repeated 6 to 10 times were clearly the most frequent $(86.3 \%$ of all microsatellites detected in silico).

Microsatellite marker development. Forward and reverse primers were successfully designed for a total of 114 loci. Within species, the number of microsatellite loci for which primers could be designed ranged between 14 (P. pini) and 38 (P. multivora), which corresponds to 19.7 to $58.1 \%$ of the initial number of reads containing microsatellites (Table 1). For the remaining reads containing microsatellite loci, the microsatellite locus was either non-ideally positioned (i.e., very close to either end of the read) for designing both primers or the same read was present more than once in the data set. In total, 73 primer pairs were tested for positive PCR amplification and polymorphism, including all 36 loci with primers for P. plurivora, 24 of 38 loci for P. multivora, and 13 of 14 loci for P. pini (Table 1). The 26 potential loci for $P$. citricola sensu stricto could not be further characterized, because the number of samples was insufficient.

In all, 72 primer pairs consistently produced PCR amplicons for a set of 16 isolates for each species (98.6\% amplification success), and 37 of these loci showed polymorphism (Table 1). The highest incidence of polymorphic loci was observed in $P$. pini (9 of 12) and the lowest in P. plurivora (11 of 36). Two loci (one in $P$. pini and one in P. multivora) for which a PCR amplicon was not consistently produced under standard PCR conditions were not further characterized.

Population genetic analyses. Linkage disequilibrium was detected between some of the microsatellite locus pairs $(P \leq 0.05$; $P$. plurivora, 43 pairs; $P$. multivora, 33 pairs; and $P$. pini, 10 pairs). However, after Bonferroni correction, the $P$ values were no longer significant.

In total, 211 isolates ( 77 for $P$. plurivora, 57 for $P$. multivora, and 77 for $P$. pini) from eight populations were analyzed, with each of them representing a different multilocus genotype. For $P$. plurivora, 75 alleles were found across all 11 loci and four populations (Table 2). At a single locus, the total number of alleles observed was 2 to 24 (mean value of 6.8). For P. multivora, allelic diversity was lower than in $P$. plurivora (2 to 10 alleles/locus), although the total number of alleles was higher (83 alleles) (Table 3). The minimum total number of alleles (37 alleles) and the lowest allelic diversity (2 to 8 alleles per locus) were observed in $P$. pini (Table 4). In all three species, an extremely low observed heterozygosity was detected at most loci in all populations (Tables 2 to 4 ).

Cross-species transferability of microsatellite loci. All new microsatellite markers amplified best for the species they were specifically developed for, followed by the other species within the former $P$. citricola complex (45 to 66\% amplification success). Amplification success significantly decreased for species of the ITS clade 2 (20 to $40 \%$ amplification success), and was even lower for species of the other ITS clades tested (7 to $19 \%$ amplification success). Frequently, PCR amplification in non-target species was inconsistent or the amplicon was outside the size range of the microsatellite in the target species (Supplemental Table 2).

Species determination using four microsatellites. $P$. plurivora, $P$. multivora, $P$. pini, and $P$. citricola sensu stricto can be discriminated based on their allele pattern at the loci PmMs04, PmMs20, Ppi03, and PpMs16. In P. plurivora, a PCR amplicon is present at loci PpiMs03 and PpMs16 but not at loci PmMs04 and PmMs20. The opposite situation is observed in P. multivora, with positive amplification only at loci PmMs04 and PmMs20. For the

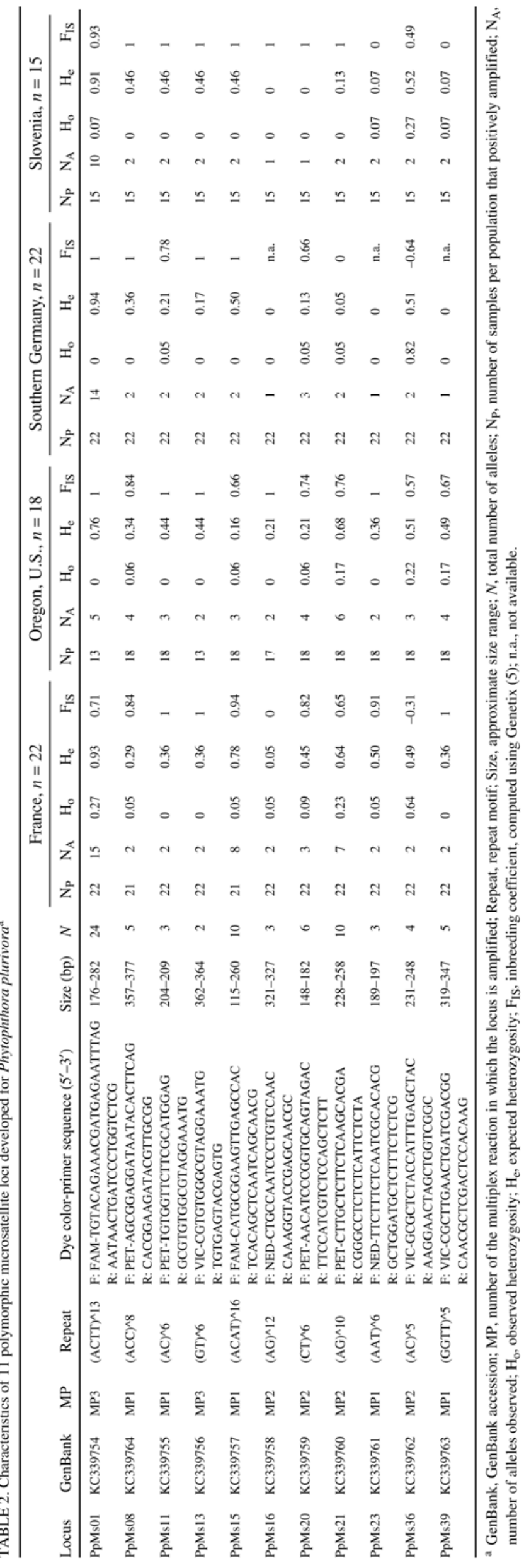

Vol. 103, No. 10, 20131023 
other two species, only a single band is visible on the gel (i.e., at locus PpiMs03 for P. pini and locus PpMs16 for P. citricola sensu stricto) (Table 5).

\section{DISCUSSION}

In the present study, we developed 35 polymorphic microsatellite markers for three Phytophthora spp. of the former $P$. citricola complex. Of the 35 microsatellites, 8 were for $P$. pini, 11 for $P$. plurivora, and 16 for $P$. multivora. These numbers are in the upper range of the number of microsatellite markers that are currently available and in use in other Phytophthora spp. $(2,11,29,35,38,39,46,49)$. In fungi and oomycetes, polymorphic microsatellite loci seem to be less frequent than in other organisms, which might be due to their smaller genome sizes (13). Moreover, Phytophthora populations for which molecular markers have been developed (e.g., $P$. ramorum and $P$. alni subsp. uniformis) show a low genetic diversity, following a recent bottleneck. This makes marker development even more difficult. For statistically well-supported analyses, at least 8 polymorphic

TABLE 3. Characteristics of 16 polymorphic microsatellite loci developed for Phytophthora multivora $a^{\mathrm{a}}$

\begin{tabular}{|c|c|c|c|c|c|c|c|c|c|c|c|c|c|c|c|c|}
\hline \multirow[b]{2}{*}{ Locus } & \multirow[b]{2}{*}{ GenBank } & \multirow[b]{2}{*}{ MP } & \multirow[b]{2}{*}{ Repeat } & \multirow[b]{2}{*}{ Dye color-primer sequence $\left(5^{\prime}-3^{\prime}\right)$} & \multirow[b]{2}{*}{ Size (bp) } & \multirow[b]{2}{*}{$N$} & \multicolumn{5}{|c|}{ Australia, $n=45$} & \multicolumn{5}{|c|}{ New Zealand, $n=12$} \\
\hline & & & & & & & $\mathrm{N}_{\mathrm{P}}$ & $\mathrm{N}_{\mathrm{A}}$ & $\mathrm{H}_{\mathrm{o}}$ & $\mathrm{H}_{\mathrm{e}}$ & $\mathrm{F}_{\mathrm{IS}}$ & $\mathrm{N}_{\mathrm{P}}$ & $\mathrm{N}_{\mathrm{A}}$ & $\mathrm{H}_{\mathrm{o}}$ & $\mathrm{H}_{\mathrm{e}}$ & $\mathrm{F}_{\mathrm{IS}}$ \\
\hline PmMs02 & KC339738 & MP1 & $(\mathrm{AAG})^{\wedge} 7$ & $\begin{array}{l}\text { F: FAM-CAGTCTGTCGTTTGGCTCC } \\
\text { R: AAACCGGTCGTATCCCTCG }\end{array}$ & $157-163$ & 2 & 45 & 2 & 0 & 0.09 & 1 & 12 & 2 & 0 & 0.16 & 1 \\
\hline PmMs04 & KC339739 & MP1 & $(\mathrm{CGT})^{\wedge} 6$ & $\begin{array}{l}\text { F: PET-GCGAACTTTGCGTACAGGG } \\
\text { R: ACACGTAGAGCTCCGTTCC }\end{array}$ & $182-194$ & 4 & 45 & 3 & 0 & 0.24 & 1 & 12 & 4 & 0 & 0.54 & 1 \\
\hline PmMs05 & KC339740 & MP1 & $(\mathrm{CTGT})^{\wedge} 10$ & $\begin{array}{l}\text { F: VIC-CAAACGATCGCCACCCTTC } \\
\text { R: ATTGCACTTCACGACGCAG }\end{array}$ & $330-373$ & 6 & 26 & 5 & 0.54 & 0.62 & 0.13 & 10 & 4 & 0.8 & 0.70 & -0.16 \\
\hline PmMs06 & KC339741 & MP1 & $(\mathrm{CT})^{\wedge} 7$ & $\begin{array}{l}\text { F: FAM-GGGCGAGATGTCCACCTAC } \\
\text { R: GTTCCGTGGCAACTTGTGG }\end{array}$ & $240-251$ & 6 & 45 & 4 & 0 & 0.57 & 1 & 12 & 5 & 0 & 0.71 & 1 \\
\hline PmMs07 & KC339742 & MP1 & $(\mathrm{CT})^{\wedge} 7$ & $\begin{array}{l}\text { F: NED-TTGCGAATTGTCCGCCATC } \\
\text { R: GCAACAAGTATCCGCCTGC }\end{array}$ & $197-205$ & 3 & 45 & 2 & 0 & 0.49 & 1 & 12 & 3 & 0 & 0.59 & 1 \\
\hline PmMs08 & KC339743 & MP2 & $(\mathrm{AG})^{\wedge} 12$ & $\begin{array}{l}\text { F: VIC-CGGACGAATGTATCTGCCC } \\
\text { R: CCTATCCATCGGCAATTCGG }\end{array}$ & $157-168$ & 10 & 45 & 8 & 0 & 0.76 & 1 & 12 & 6 & 0 & 0.72 & 1 \\
\hline PmMs09 & KC339744 & MP4 & $(\mathrm{CT})^{\wedge} 7$ & $\begin{array}{l}\text { F: FAM-GAGGTTGGGCATTTGCCAG } \\
\text { R: CTCGTTGCAGTGGGCATTC }\end{array}$ & $354-391$ & 5 & 43 & 5 & 0 & 0.72 & 1 & 11 & 3 & 0 & 0.62 & 1 \\
\hline PmMs 10 & KC339745 & MP2 & $(\mathrm{AG})^{\wedge} 6$ & $\begin{array}{l}\text { F: NED-GTAGGTGCTGAGGAAACGC } \\
\text { R: CGCCACGCTGGACATTTG }\end{array}$ & 197-204 & 5 & 45 & 4 & 0 & 0.47 & 1 & 12 & 4 & 0 & 0.68 & 1 \\
\hline PmMs12 & KC339746 & MP2 & $(\mathrm{CGT})^{\wedge} 6$ & $\begin{array}{l}\text { F: FAM-CCTTTCACCTCTCAAGACGC } \\
\text { R: AGTCCACCGAAACGAGTGC }\end{array}$ & $184-222$ & 3 & 45 & 3 & 0 & 0.20 & 1 & 12 & 2 & 0 & 0.39 & 1 \\
\hline PmMs14 & КC339747 & MP3 & $(\mathrm{GCT})^{\wedge} 6$ & $\begin{array}{l}\text { F: NED-TCGTTTGGGCATTGGAACG } \\
\text { R: GACATGTAGCGGAGACGGG }\end{array}$ & $249-256$ & 5 & 45 & 3 & 0 & 0.67 & 1 & 12 & 2 & 0 & 0.16 & 1 \\
\hline PmMs 18 & КC339748 & MP3 & $(\mathrm{AG})^{\wedge} 7$ & $\begin{array}{l}\text { F: PET-GCAACAAGTATCCGCCTGC } \\
\text { R: TTGCGAATTGTCCGCCATC }\end{array}$ & 193-02 & 6 & 45 & 5 & 0 & 0.61 & 1 & 9 & 3 & 0 & 0.60 & 1 \\
\hline PmMs19 & КC339749 & MP4 & $(\mathrm{CG})^{\wedge} 6$ & $\begin{array}{l}\text { F: FAM-GCGTGACGAGAATACAGCC } \\
\text { R: CCACATTTGCCGCCTCTAC }\end{array}$ & $208-217$ & 3 & 43 & 2 & 0.05 & 0.05 & -0.01 & 11 & 2 & 0.09 & 0.09 & 0 \\
\hline PmMs20 & KC339750 & MP1 & $(\mathrm{CG})^{\wedge} 6$ & $\begin{array}{l}\text { F: PET-GGCACTTATACACCTTTGCCC } \\
\text { R: CACGAGGCAGGGTAGTTGG }\end{array}$ & $239-251$ & 5 & 30 & 5 & 0 & 0.45 & 1 & 5 & 2 & 0 & 0.53 & 1 \\
\hline PmMs21 & КC339751 & MP2 & $(\mathrm{AG})^{\wedge} 8$ & $\begin{array}{l}\text { F: FAM-TTCTGTGGGAAGGAACCCG } \\
\text { R: GACGGGAAATACGTGACCG }\end{array}$ & 289-297 & 5 & 45 & 4 & 0 & 0.63 & 1 & 12 & 4 & 0 & 0.54 & 1 \\
\hline PmMs23 & KC339752 & MP4 & $(\mathrm{CT})^{\wedge} 7$ & $\begin{array}{l}\text { F: VIC-AGGTCAGGCGACAACTCTG } \\
\text { R: CTCTTCTTGCTTCCGGCAC }\end{array}$ & $217-247$ & 9 & 24 & 7 & 0.21 & 0.57 & 0.64 & 9 & 6 & 0.22 & 0.77 & 0.72 \\
\hline PmMs24 & KC339753 & MP3 & $(\mathrm{AG})^{\wedge} 6$ & $\begin{array}{l}\text { F: PET-ATGCTAGCGGACAGGCTAC } \\
\text { R: CGTCGAATTGTCTTCCGGC }\end{array}$ & $383-388$ & 6 & 45 & 4 & 0 & 0.52 & 1 & 12 & 5 & 0 & 0.70 & 1 \\
\hline
\end{tabular}

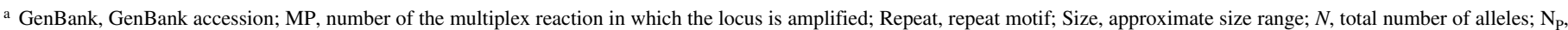
number of samples per population that positively amplified; $\mathrm{N}_{\mathrm{A}}$, number of alleles observed; $\mathrm{H}_{\mathrm{o}}$, observed heterozygosity; $\mathrm{H}_{\mathrm{e}}$, expected heterozygosity; $\mathrm{F}_{\mathrm{IS}}$, inbreeding coefficient, computed using Genetix (5).

TABLE 4. Characteristics of eight polymorphic microsatellite loci developed for Phytophthora pini ${ }^{\text {a }}$

\begin{tabular}{|c|c|c|c|c|c|c|c|c|c|c|c|c|c|c|c|c|c|c|c|c|}
\hline \multirow[b]{2}{*}{ Locus } & \multirow[b]{2}{*}{ GenBank } & \multirow[b]{2}{*}{ Repeat } & \multirow[b]{2}{*}{ Primer sequence $\left(5^{\prime}-3^{\prime}\right)$} & \multirow[b]{2}{*}{ Size (bp) } & \multirow[b]{2}{*}{$N$} & \multicolumn{5}{|c|}{$\begin{array}{c}\text { Europe, } \\
n=18\end{array}$} & \multicolumn{5}{|c|}{$\begin{array}{l}\text { United States, East } \\
\text { Coast, } n=22\end{array}$} & \multicolumn{5}{|c|}{$\begin{array}{l}\text { United States, Oregon, } \\
\qquad n=37\end{array}$} \\
\hline & & & & & & $\mathrm{N}_{\mathrm{P}}$ & $\mathrm{N}_{\mathrm{A}}$ & $\mathrm{H}_{\mathrm{o}}$ & $\mathrm{H}_{\mathrm{e}}$ & $\mathrm{F}_{\mathrm{IS}}$ & $\mathrm{N}_{\mathrm{P}}$ & $\mathrm{N}_{\mathrm{A}}$ & $\mathrm{H}_{\mathrm{o}}$ & $\mathrm{H}_{\mathrm{e}}$ & $\mathrm{F}_{\mathrm{IS}}$ & $\mathrm{N}_{\mathrm{P}}$ & $\mathrm{N}_{\mathrm{A}}$ & $\mathrm{H}_{\mathrm{o}}$ & $\mathrm{H}_{\mathrm{e}}$ & $\mathrm{F}_{\mathrm{IS}}$ \\
\hline PpiMs01 & KC339730 & $(\mathrm{AG})^{\wedge} 6$ & $\begin{array}{l}\text { F: TTAACGGACTGCGACCTCC } \\
\text { R: CCCAACTTAACCAACGGGC }\end{array}$ & $348-365$ & 5 & 17 & 3 & 0 & 0.53 & 1 & 22 & 4 & 0 & 0.53 & 1 & 36 & 2 & 0 & 0.49 & 1 \\
\hline PpiMs03 & KC339731 & $(\mathrm{CT})^{\wedge} 6$ & $\begin{array}{l}\text { F: AAGTTGGTGGCGCTTTGAC } \\
\text { R: TGTGCCTTGCACTTTGACC }\end{array}$ & $248-250$ & 2 & 10 & 1 & 0 & 0 & - & 21 & 2 & 0 & 0.42 & 1 & 32 & 2 & 0 & 0.31 & 1 \\
\hline PpiMs05 & KC339732 & $(\mathrm{GCT})^{\wedge} 6$ & $\begin{array}{l}\text { F: CCATTGACGACAGTTGGCTC } \\
\text { R: CTACGATTCCGCGTCCAAG }\end{array}$ & 187-199 & 3 & 18 & 3 & 0 & 0.20 & 1 & 21 & 3 & 0 & 0.18 & 1 & 35 & 2 & 0 & 0.11 & 1 \\
\hline PpiMs08 & КC339733 & $(\mathrm{AT})^{\wedge} 6$ & $\begin{array}{l}\text { F: ACCGATAGCATTTATTCTGAGCC } \\
\text { R: CGGCAGACTGTAAATTTGTTGAAG }\end{array}$ & 279-291 & 4 & 17 & 3 & 0 & 0.22 & - & 21 & 2 & 0 & 0.32 & - & 35 & 4 & 0 & 0.34 & 1 \\
\hline PpiMs09 & КC339734 & $(\mathrm{CTT})^{\wedge} 7$ & $\begin{array}{l}\text { F: CGTTGAAGTCAGCCATCTCG } \\
\text { R: ACTGGTGAAGACGGACTCG }\end{array}$ & $291-211$ & 8 & 18 & 3 & 0 & 0.3 & 1 & 22 & 6 & 0.04 & 0.70 & 0.9 & 37 & 5 & 0.03 & 0.57 & 1 \\
\hline PpiMs10 & KC339735 & $(\mathrm{AC})^{\wedge} 6$ & $\begin{array}{l}\text { F: GCGCATTGGATTCTCCATAAC } \\
\text { R: GCGGGTAAATCCCAGTTGC }\end{array}$ & $357-387$ & 8 & 16 & 2 & 0.88 & 0.51 & -0.8 & 20 & 6 & 1 & 0.79 & -0.3 & 36 & 6 & 0.94 & 0.75 & - \\
\hline PpiMs12 & KC339736 & $(\mathrm{AT})^{\wedge} 6$ & $\begin{array}{l}\text { F: AGGAGAAATGGCTGAGTGG } \\
\text { R: TGAGCCAGGATACAACTCTATTG }\end{array}$ & $286-297$ & 3 & 11 & 1 & 0 & 0 & - & 15 & 2 & 0 & 0.24 & 1 & 30 & 3 & 0 & 0.13 & 1 \\
\hline PpiMs13 & KC339737 & $(\mathrm{CT})^{\wedge} 6$ & $\begin{array}{l}\text { F: TCCTTTCCAGGGCCTTCAG } \\
\text { R: GCAGTTCACAGACCAACGG }\end{array}$ & $187-300$ & 4 & 18 & 2 & 0 & 0.36 & 1 & 22 & 2 & 0 & 0.17 & 1 & 35 & 4 & 0.03 & 0.48 & 0.9 \\
\hline
\end{tabular}

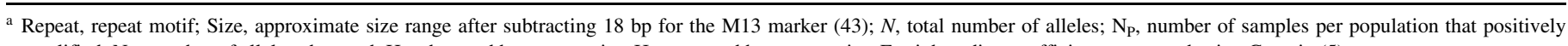
amplified; $\mathrm{N}_{\mathrm{A}}$, number of alleles observed; $\mathrm{H}_{\mathrm{o}}$, observed heterozygosity; $\mathrm{H}_{\mathrm{e}}$, expected heterozygosity; $\mathrm{F}_{\mathrm{IS}}$, inbreeding coefficient, computed using Genetix (5). 
microsatellite loci (in some studies, even up to 11) (48) are generally recommended. Therefore, the number of markers we developed is most likely sufficient to investigate the biology and epidemiology of the three target species.

Our work shows that the state-of-the-art 454-pyrosequencingtechnology to develop microsatellite markers (1) is well applicable to Phytophthora spp. Using this method, microsatellite development in fungi, including oomycetes, is no longer as difficult as Dutech et al. (13) reported for the traditional method, which involves the construction of an enriched library. However, the success of transferability of microsatellite markers to other Phytophthora spp. is low, especially when the target species are genetically not closely related. A lower cross-species transferability of microsatellite markers in fungi (and oomycetes) compared with plants and animals was previously detected by Dutech et al. (13). Therefore, this solution does not seem to be particularly appropriate for developing markers for new fungal species.

A limitation of 454-pyrosequencing-technology could be that very long microsatellite loci (i.e., with motifs repeated 20 to 50 times) may not be detectable. For instance, we found only one single polymorphic microsatellite with the motif repeated $>15$ times. The average read length obtained with a Roche GS FLX sequencer, such as the one used in the present study, is 250 to 300 $\mathrm{bp}$, which means that, for a long microsatellite locus to be amplifiable, it needs be in a perfect position (i.e., very close to the center of the sequence). Unfortunately, as we observed in our study, microsatellite loci are frequently located at one or other end of the read so that one of the two primers cannot be designed. This limitation may be overcome by the latest GS FLX+ technology, which creates reads up to 1,000 bp (http://454.com/ products/gs-flx-system/index.asp). It seems, however, that the scarcity of long microsatellite loci in fungi and oomycetes is real (13) and, thus, can only be slightly modifiable by choosing a particular method of microsatellite isolation.

In all three Phytophthora spp. investigated, $\approx 80 \%$ of the microsatellite loci detected in silico were composed of dinucleotide repeat motifs. This confirms the previous findings of Karaoglu et al. (27) that dinucleotide microsatellites are the most frequent microsatellites in fungi. In contrast, in higher eukaryotic genome microsatellites with trinucleotide, repeat motifs seem to be dominant (47).

A high level of homozygosity at most loci was detected in all populations for all three species tested, unlike with other Phytophthora spp. such as $P$. cinnamomi (10), P. infestans (29), $P$. megakarya (35), and $P$. ramorum $(22,38)$, where microsatellites did not reveal such a high deficit of heterozygosity. In contrast to $P$. plurivora, $P$. pini, and $P$. multivora, which are homothallic (i.e., able to self fertilize), all these other species are heterothallic (i.e., require two mating types for sexual reproduction). Hence, the excess of homozygosity found in our analyses might be due to the homothallic mating system of our Phytophthora spp. (17). Although homothallism is common in the genus Phytophthora and $62 \%$ of all species listed in Martin et al. (33) are homothallic, most species for which microsatellite markers are currently available and in use are heterothallic, except for $P$. sojae and $P$. alni subsp. uniformis. Although data for $P$. alni subsp. uniformis points in the same direction (high $\mathrm{F}_{\mathrm{IS}}$ values and low heterozygosity) (2), a larger set of isolates of all four species should be analyzed to confirm or reject our hypothesis. Alternatively, the dominance of homozygotes might suggest a strong presence of null alleles. However, this situation is observable at most loci in all populations and, hence, null alleles alone are unlikely to explain it.

Four of our microsatellites may be useful not only for population genetic analyses but also for discriminating the four Phytophthora spp. of the former $P$. citricola complex. Without molecular tools, identifying Phytophthora spp. in the laboratory is rather difficult because some of the morphological characteristics of cultures (e.g., oospore wall index, presence of hyphal swellings, and sporangium morphology) may be misleading. Sequencing specific DNA regions is a widely applied method for identifying Phytophthora spp. (28). Analyzing the allele patterns on a gel at the four microsatellite loci that we selected is an economic and easy way to rapidly screen $P$. citricola sensu lato isolates.

TABLE 5. Identification of Phytophthora plurivora, P. multivora, P. pini, and P. citricola sensu stricto using the four newly developed microsatellite markers PmMs04, PmMs20, PpiMs03, and PpMs16

\begin{tabular}{|c|c|c|c|c|}
\hline Isolates & PmMs04 & PmMs20 & PpiMs03 & PpMs16 \\
\hline P. plurivora & - & - & + & + \\
\hline CBS 22188 (Taiwan) & - & - & + & + \\
\hline CS737 (New Zealand) & - & - & + & + \\
\hline CS740 (New Zealand) & - & - & + & + \\
\hline CS763 (New Zealand) & - & - & + & + \\
\hline CBS 124087 (Germany) & - & - & + & + \\
\hline P. multivora & + & + & - & - \\
\hline CS452 (Italy) & + & + & - & - \\
\hline CS461 (Italy) & + & + & - & - \\
\hline CS466 (Italy) & + & + & - & - \\
\hline CS739 (New Zealand) & + & + & - & - \\
\hline CBS 111337 (South Korea) & + & + & - & - \\
\hline CBS 124094 (Australia) & + & + & - & - \\
\hline P. pini & - & - & + & - \\
\hline CS440 (Italy) & - & - & - & + \\
\hline CS449 (Italy) & - & - & - & + \\
\hline CS464 (Italy) & - & - & - & + \\
\hline CS645 (Italy) & - & - & - & + \\
\hline CBS 29529 (Japan) & - & - & - & + \\
\hline
\end{tabular}

a Symbols: +, positive polymerase chain reaction (PCR) amplification and -, no PCR amplicon. 


\section{ACKNOWLEDGMENTS}

DNA sequencing and fragment analyses was carried out at the Genetic Diversity Centre of ETH Zurich. We thank S. Werres, F. Fleischmann, J. Nechwatal (Germany), A. Munda (Slovenia), N. Grünwald, E. Hansen, S. Jeffers, Y. Balci (United States), C. Husson, R. Ioos (France), J. Kovacs, J. Bakonyi (Hungary), L. Orlikowski, T. Oszako (Poland), T. Burgess (Australia), M. Pánek (Czech Republic), and N. Williams (New Zealand) for contributing samples; D. Rigling for his helpful comments; COST Switzerland (project no. SER C10.0129) for funding this study; and S. Dingwall for the English check.

\section{LITERATURE CITED}

1. Abdelkrim, J., Robertson, B. C., Stanton, J. A. L., and Gemmell, N. J. 2009. Fast, cost-effective development of species-specific microsatellite markers by genomic sequencing. BioTechniques 46:185-192.

2. Aguayo, J., Adams, G. C., Halkett, F., Catal, M., Husson, C., Nagy Z. A., Hansen, E. M., Marcais, B., and Frey, P. 2013. Strong genetic differentiation between North American and European populations of Phytophthora alni subsp. uniformis. Phytopathology 103:190-199.

3. Anderson, P. K., Cunningham, A. A., Patel, N. G., Morales, F. J., Epstein, P. R., and Daszak, P. 2004. Emerging infectious diseases of plants: Pathogen pollution, climate change and agrotechnology drivers. Trends Ecol. Evol. 19:535-544.

4. Barbara, T., Palma-Silva, C., Paggi, G. M., Bered, F., Fay, M. F., and Lexer, C. 2007. Cross-species transfer of nuclear microsatellite markers: Potential and limitations. Mol. Ecol.16:3759-3767.

5. Belkhir, K., Borsa, P., Chikhi, L., Raufaste, N., and Bonhomme, F. 2004. GENETIX. http://kimura.univ-montp2.fr/genetix/

6. Blair, J. E., Coffey, M. D., Park, S. Y., Geiser, D. M., and Kang, S. 2008. A multi-locus phylogeny for Phytophthora utilizing markers derived from complete genome sequences. Fungal Genet. Biol. 45:266-277.

7. Birch, P. R. J., and Whisson, S.C. 2001. Phytophthora infestans enters the genomics era. Mol. Plant Pathol. 2:257-263.

8. Cooke, D. E. L., Drenth, A., Duncan, J. M., Wagels, G., and Brasier, C. M. 2000. A molecular phylogeny of Phytophthora and related oomycetes. Fungal Genet. Biol. 30:17-32.

9. Desprez-Loustau, M. L., Robin, C., Buée, M., Courtecuisse, R., Garbaye, J., Suffert, F., Sache, I., and Rizzo, D. M. 2007. The fungal dimension of biological invasions. Trends Ecol. Evol. 22:472-480.

10. Dobrowolski, M. P., Tommerup, I. C., Shearer, B. L., and O'Brien, P. A. 2003. Three clonal lineages of Phytophthora cinnamomi in Australia revealed by microsatellites. Phytopathology 93:695-704.

11. Durán, A., Gryzenhout, M., Slippers, B., Ahumada, R., Rotella, A., Flores, F., Wingfield, B. D., and Wingfield, M. J. 2008. Phytophthora pinifolia sp. nov. associated with a serious needle disease of Pinus radiata in Chile. Plant Pathol. 57:715-727.

12. Dutech, C., Barrès, B., Bridier, J., Robin, C., Milgroom, M. G., and Ravigné, V. 2012. The chestnut blight fungus world tour: Successive introduction events from diverse origins in an invasive plant fungal pathogen. Mol. Ecol. 21:3931-3946.

13. Dutech, C., Enjalbert, J., Fournier, E., Delmotte, F., Barrès, B., Carlier, J., Tharreau, D., and Giraud, T. 2007. Challenges of microsatellite isolation in fungi. Fungal Genet. Biol. 44:933-949.

14. Erwin, D. C., and Ribeiro, O. K. 1996. Phytophthora Diseases Worldwide. American Phytopathological Society, St. Paul, MN.

15. Faircloth, B. C. 2008. MSATCOMMANDER: Detection of microsatellite repeat arrays and automated, locus-specific primer design. Mol. Ecol. Res. 8:92-94.

16. Goldstein, D. B., and Schlotterer, C. 1999. Microsatellites: Evolution and Applications. Oxford University Press, Oxford.

17. Goodwin, S. B. 1997. The population genetics of Phytophthora. Phytopathology 87:462-473.

18. Goss, E. M., Larsen, M., Vercauteren, A., Werres, S., Heungens, K., and Grünwald, N. J. 2011. Phytophthora ramorum in Canada: Evidence for migration within North America and from Europe. Phytopathology 101:166-171.

19. Goudet, J. 2001. FSTAT, A Program to Estimate and Test Gene Diversities and Fixation Indices, Version 2.9.3, Department of Ecology and Evolution, University of Lausanne, Switzerland. http://www2.unil.ch/ popgen/softwares/fstat.htm

20. Grünwald, N. J., Garbelotto, M., Goss, E. M., Heungens, K., and Prospero, S. 2012. Emergence of the sudden oak death pathogen Phytophthora ramorum. Trends Microbiol. 20:131-138.

21. Hong, C., Gallegly, M. E., Richardson, P. A., and Kong, P. 2011. Phytophthora pini Leonian resurrected to distinct species status. Mycologia 103:351-60.22.

22. Ivors, K., Garbelotto, M., Vries, I. D. E., Ruyter-Spira, C. B., Hekkert, T.,
Rosenzweig, N., and Bonants, P. 2006. Microsatellite markers identify three lineages of Phytophthora ramorum in US nurseries, yet single lineages in US forest and European nursery populations. Mol. Ecol. 15:1493-1505.

23. Jarne, P., and Lagoda, P. J. L. 1996. Microsatellites, from molecules to populations and back. Trends Ecol. Evol. 11:424-429.

24. Jung, T. 2009. Beech decline in Central Europe driven by the interaction between Phytophthora infections and climatic extremes. For. Pathol. 39:73-94.

25. Jung, T., Blaschke, H., and Oßwald, W. 2000. Involvement of soilborne Phytophthora species in Central European oak decline and the effect of site factors on the disease. Plant Pathol. 49:706-718.

26. Jung, T., and Burgess, T. I. 2009. Re-evaluation of Phytophthora citricola isolates from multiple woody hosts in Europe and North America reveals a new species, Phytophthora plurivora sp. nov. Persoonia 22:95-110.

27. Karaoglu, H., Lee, C. M. Y., and Meyer, W. 2004. Survey of simple sequence repeats in completed fungal genomes. Mol. Biol. Evol. 22:639649.

28. Kroon, L. P. N. M., Brouwer, H., de Cock, A. W. A. M., and Govers, F. 2011. The Genus Phytophthora Anno 2012. Phytopathology 102:348-364.

29. Lees, A. K., Wattier, R., Shaw, D. S., Sullivan, L., Williams, N. A., and Cooke, D. E. L. 2006. Novel microsatellite markers for the analysis of Phytophthora infestans populations. Plant Pathol. 55:311-319.

30. Liebhold, A. M., Brockerhoff, E. G., Garrett, L. J., Parke, J. L., and Britton, K. O. 2012. Live plant imports: The major pathway for forest insect and pathogen invasions of the US. Front. Ecol. Environ. 10:135143.

31. Loo, J. A. 2009. Ecological impacts of non-indigenous invasive fungi as forest pathogens. Biol. Invas. 11:81-96.

32. Margulies, M., Egholm, M., Altman, W. E., Attiya, S., Bader, J. S., Bemben, L. A. Berka, J., Braverman, M. S., Chen, Y. J., Chen, Z. T., Dewell, S. B., Du, L., Fierro, J. M., Gomes, X. V., Godwin, B. C., He, W., Helgesen, S., Ho, C. H, Irzyk, G. P., Jando, S. C., Alenquer, M. L. I., Jarvie, T. P., Jirage, K. B., Kim, J. B., Knight, J. R., Lanza, J. R., Leamon, J. H., Lefkowitz, S. M., Lei, M., Li, J., Lohman, K. L., Lu, H., Makhijani, V. B., McDade, K. E., McKenna, M. P., Myers, E. W., Nickerson, E., Nobile, J. R., Plant, R., Puc, B. P., Ronan, M. T., Roth, G. T., Sarkis, G. J., Simons, J. F., Simpson, J. W., Srinivasan, M., Tartaro, K. R., Tomasz, A., Vogt, K. A., Volkmer, G. A., Wang, S. H., Wang, Y., Weiner, M. P., Yu, P. G., Begley, R. F., and Rothberg, J. M. 2005. Genome sequencing in microfabricated high-density picolitre reactors. Nature 437:376-380.

33. Martin, F. N., Abad, Z. G., Balci, Y., and Ivors, K. 2012. Identification and detection of Phytophthora: Reviewing our progress, identifying our needs. Plant Dis. 96:1080-1103.

34. McKinney, L. V., Thomsen, I. M., Kjær, E. D., and Nielsen, L. R. 2011. Genetic resistance to Hymenoscyphus pseudoalbidus limits fungal growth and symptom occurrence in Fraxinus excelsior. For. Pathol. 42:69-74.

35. Mfegue, C. V., Herail, C., Adreit, H., Mbenoun, M., Techou, Z., Ten Hoopen, M., Tharreau, D., and Ducamp, M. 2012. Microsatellite markers for population studies of Phytophthora megakarya (Pythiaceae), a cacao pathogen in Africa. Am. J. Bot. 99:e353-e356.

36. Miller, P. M. 1955. V8 Juice agar as a general-purpose medium for fungi and bacteria. Phytopathology 45:461-462.

37. Moralejo, E., Pérez-Sierra, A. M., Alvarez, L. A., Belbahri, L., Lefort, F., and Descals, E. 2009. Multiple alien Phytophthora taxa discovered on diseased ornamental plants in Spain. Plant Pathol. 58:100-110.

38. Prospero, S., Black, J. A., and Winton, L. M. 2004. Isolation and characterization of microsatellite markers in Phytophthora ramorum, the causal agent of sudden oak death. Mol. Ecol. Notes 4:672-674.

39. Prospero, S., Grünwald, N. J., Winton, L. M., and Hansen, E. M. 2009. Migration Patterns of the Emerging Plant Pathogen Phytophthora ramorum on the West Coast of the United States of America. Phytopathology 99:739-749.

40. Rozen, S., and Skaletsky H. J. 2000. Primer3 on the www for general users and for biologist programmers. In: Bioinformatics Methods and Protocols: Methods in Molecular Biology. S. Krawetz and S. Misener, eds. Humana Press, Totowa, NJ.

41. Sawada, K. 1927. Descriptive catalogue of the Formosan fungi. Part III. Rep. Dep. Agric. Res. Inst. Formosa.

42. Schoebel, C. N., Brodbeck, S., Buehler, D., Cornejo, C., Gajurel, J., Hartikainen, H., Keller, D., Leys, M., Ríčanová, Š., Segelbacher, G., Werth, S., and Csencsics, D. 2013. Lessons learned from microsatellite development for non-model organisms using 454 pyrosequencing. J. Evol. Biol. 26:600-611.

43. Schuelke, M. 2000. An economic method for the fluorescent labelling of PCR fragments. Nat. Biotechnol. 18:233-234.

44. Scott, P. M., Burgess, T. I., Barber, P. A., Shearer, B. L., Stukely, M. J. C., Hardy, G. S. J., and Jung, T. 2009. Phytophthora multivora sp. nov., a new species recovered from declining Eucalyptus, Banksia, Agonis and other plant species in western Australia. Persoonia 22:1-13. 
45. Selkoe, K. A., and Toonen, R. J. 2006. Microsatellites for ecologists: A practical guide to using and evaluating microsatellite markers. Ecol. Lett. 9:615-629.

46. Stewart, S., Wickramasinghe, D., Dorrance, A. E., and Robertson, A. E. 2011. Comparison of three microsatellite analysis methods for detecting genetic diversity in Phytophthora sojae (Stramenopila: Oomycete). Biotechnol. Lett. 33:2217-2223.

47. Subramanian, S., Madgula, V. M., George, R., Mishra, R. K., Pandit, M.W., Kumar, C. S., and Singh, L. 2003. Triplet repeats in human genome: distribution and their association with genes and other genomic regions Bioinformatics 19:549-552.

48. van Asch, B., Pinheiro, R., Pereira, R., Alves, C., Pereira, V., Pereira, F., Gusmão, L., and Amorim, A. 2010. A framework for the development of STR genotyping in domestic animal species: Characterization and population study of 12 canine X-chromosome loci. Electrophoresis 31:303-308.

49. Vercauteren, A., De Dobbelaere, I., Grünwald, N. J., Bonants, P., Van Bockstaele, E., Maes, M., and Heungens, K. 2009. Clonal expansion of the Belgian Phytophthora ramorum populations based on new microsatellite markers. Mol. Ecol. 19:92-107.

50. Weir, B. S., and Cockerham, C. C. 1984. Estimating F statistics for the analysis of population structure. Evolution 38:1358-1370.

51. White, T., Bruns, T., Lee, S., and Taylor, J. 1990. Amplification and direct sequencing of fungal ribosomal RNA genes for phylogenetics. In: PCR Protocols: A Guide to Methods and Applications. M. Innis, D. Gelfand, J. Sninsky, and T. White, eds. Academic Press, New York.

52. Zane, L., Bargelloni, L., and Patarnello, T. 2002. Strategies for microsatellite isolation: A review. Mol. Ecol. 11:1-16. 